\title{
Determination of Glycerin from a Marketed Personal Care Product Using Gas Chromatography
}

\author{
Amit Kumar De, Partha Pratim Chowdhury, and Shyama Prasad Chattopadhyay
}

R\&D Division, Dey's Medical Stores (Mfg.) Ltd., 62 Bondel Road, Kolkata, West Bengal 700019, India

Correspondence should be addressed to Amit Kumar De; amitkumarde200401@gmail.com

Received 20 September 2014; Revised 25 December 2014; Accepted 16 January 2015

Academic Editor: Maria Cristina Bonferoni

Copyright (C) 2015 Amit Kumar De et al. This is an open access article distributed under the Creative Commons Attribution License, which permits unrestricted use, distribution, and reproduction in any medium, provided the original work is properly cited.

\begin{abstract}
The current study presents a packed column gas chromatographic technique for the estimation of glycerin using a flame ionization detector from a marketed hair tonic in presence of resorcinol, ethanol, biotin, keratin hydrolysate, undecylenic acid alkylolamide (hyalkyl HBU), D-biotin, nicotinic acid, and polyvinylpyrrolidone. The validation studies show the proposed method to be specific, sensitive, precise, and accurate. The method is found to be linear in the concentration range $1.25 \mathrm{mg} / \mathrm{mL}$ to $10.02 \mathrm{mg} / \mathrm{mL}$ with $r^{2}$ value 0.99 . The limit of detection and the limit of quantitation were $0.01 \mathrm{mg} / \mathrm{mL}$ and $0.05 \mathrm{mg} / \mathrm{mL}$, respectively. The method does not involve any complex sample preparation procedure and is therefore suitable for regular analysis of glycerin from marketed hair tonic.
\end{abstract}

\section{Introduction}

Glycerin is a trihydroxy alcohol having a number of commercial applications. It is colourless, odourless, syrupy liquid having a sweet taste and finds wide applications in many liquid pharmaceutical formulations [1]. Other applications include its use as a lubricant and humectants and in cosmetics [2-4]. It is used in almost all types of personal care products including medicated hair tonics [2]. It has also been tried in nursing pig diet [5] and diet of bulls. It is an important by-product obtained through biodiesel production [6]. In case of pharmaceutical formulations glycerin is manly used as an excipient [1] and variation in proportion may potentially affect the usefulness of such formulations. As humectants in cosmetic formulations and in hair tonics where it has been used as an active ingredient [7] a variation in the proportion of glycerin may spoil the quality of the product. A proper validated quantification technique for glycerin from hair tonics is therefore essential.

An extensive literature review presents a large number of methods for the estimation of glycerine. Apart from chemical analysis $[8,9]$ other methods include its estimation from biodiesel using EASI-MS technology or other food and pharmaceutical formulations $[10,11]$ and glycerin fatty acid esters
[12] and using enzymatic reactions [13]. Most of the methods involved a chromatographic technique which may be either high performance liquid chromatography [14] or a gas chromatography-mass spectroscopic technique [11] or capillary gas chromatographic technique [15]. These methods in general are costly and time consuming as most of these methods involved the preparation of a derivative [16] and subsequent quantification of the analyte. In this study we have developed a simple, rapid, precise, accurate, and cost effective technique for the quantification of glycerin in presence of complex matrix comprising resorcinol, ethanol, biotin, keratin hydrolysate, hyalkyl HBU, D-biotin, nicotinic acid, and polyvinylpyrrolidone. The sample preparation is very simple and does not involve any steps for preparation of derivatives. The process is therefore suitable for routine analysis of glycerine from hair tonics.

\section{Material and Methods}

2.1. Materials. Glycerin reference standard was purchased from Sigma Aldrich (Bangalore, India) Ltd. The sample formulation Keo Karpin Hair Vitalizer (a hair tonic) with manufacturing date December 2013, expiry date May 2016, and batch number 1119 was kindly provided by Dey's Medical 


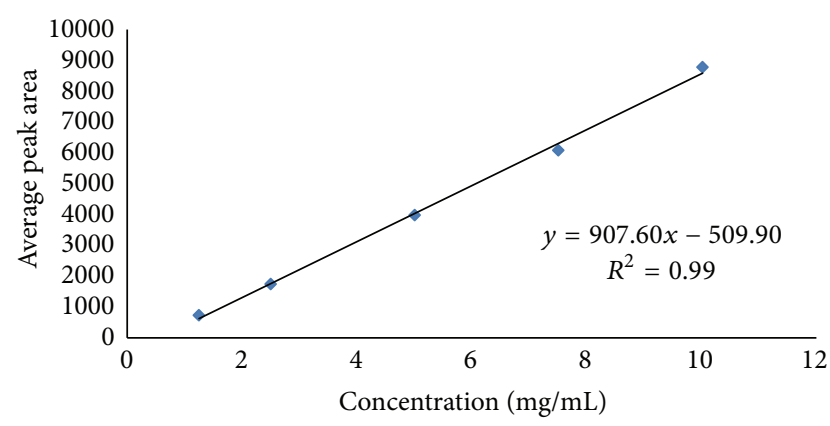

FIGURE 1: Average peak area versus concentration curve for glycerin.

Stores (Mfg.) Ltd. (Kolkata, India) in form of gift sample. GC glass column $2 \mathrm{~m} \times 3 \mathrm{~mm}$ packed with acid-washed silanised, flux-calcined siliceous earth coated with $10 \%$ diethylene glycol succinate (Chromatopak, India; Sr. number 100534934) was used for analysis. The carrier gas nitrogen and other gases-hydrogen and air of zero grade-were purchased from BOC India and Paxair India Limited. Water of Milli-Q grade was used as diluents throughout.

2.2. Equipment. The analysis was carried out on GC Ceres 800 plus (Chemito Technologies Pvt. Ltd.; Mumbai, India, now ThermoFischer Scientific, USA) with Sr. number 905/0907. The system was equipped with packed flame ionization detector (FID) and electron capture detector (ECD). The analysis was carried out in FID using packed injector port. The data acquisition and processing were carried out using Iris 32 software (Chemito Technologies Pvt. Ltd., Mumbai, India).

\subsection{Preparation of Solutions}

2.3.1. Glycerin Stock Standard Solution. The glycerin stock standard solution was prepared by dissolving $31.32 \mathrm{~g}$ of glycerin standard in $100 \mathrm{~mL}$ water (solution A). This solution was diluted in series to obtain solutions of concentrations $1.25 \mathrm{mg} / \mathrm{mL}$ to $10.02 \mathrm{mg} / \mathrm{mL}$. This same solution was spiked into sample solution for carrying out the recovery study. A five-point calibration curve was drawn for linearity study and for quantification purpose (Figure 1). Each dilution of the stock was injected in triplicates (Table 1). The least square method was used for the curve fitting purpose.

2.3.2. Test Solution. The test solution was prepared by diluting the sample hair tonic in water to obtain a solution of concentration $5.0 \mathrm{mg} / \mathrm{mL}$ of glycerin in water.

2.4. Chromatographic Condition. We used glass column $2 \mathrm{~m} \times$ $3 \mathrm{~mm}$ packed with acid-washed silanised, flux-calcined siliceous earth coated with $10 \%$ diethylene glycol succinate column. The column temperature or the oven temperature was $200^{\circ} \mathrm{C}$ throughout a single run. The detector and the injector port were maintained at $280^{\circ} \mathrm{C}$. We used Chemito packed injector port for analysis. The carrier gas flowrate was $30.00 \mathrm{~mL} / \mathrm{min}$. The air flow was $37.50 \mathrm{~mL} / \mathrm{min}$ and the
TABLE 1: GC linearity.

\begin{tabular}{lccccc}
\hline $\begin{array}{l}\text { Solutions } \\
\begin{array}{l}\text { Concentration } \\
\text { in mg/mL }\end{array}\end{array}$ & 1.25 & 2.50 & 5.01 & 7.51 & 10.02 \\
$\begin{array}{l}\text { Replicate 1 } \\
\text { (peak area) }\end{array}$ & 735.54 & 1722.89 & 3985.59 & 6011.08 & 8766.39 \\
$\begin{array}{l}\text { Replicate 2 } \\
\text { (peak area) }\end{array}$ & 731.92 & 1759.69 & 3966.59 & 6109.77 & 8765.87 \\
$\begin{array}{l}\text { Replicate 3 } \\
\text { (peak area) }\end{array}$ & 735.66 & 1753.96 & 3985.56 & 6115.84 & 8788.37 \\
\hline $\begin{array}{l}\text { Average } \\
\text { S.D. }\end{array}$ & 734.37 & 1745.51 & 3979.25 & 6078.89 & 8773.54 \\
\%RSD & 2.12 & 19.79 & 10.96 & 58.81 & 12.84 \\
\hline
\end{tabular}

hydrogen $40 \mathrm{~mL} / \mathrm{min}$. Each time $1 \mu \mathrm{L}$ of standard/sample was injected and the run time was 12 minutes.

2.5. Validation of the Developed Method. The analytical method was validated as per USP [17] and ICH guidelines [18]. The studied parameters are specificity, accuracy, precision, linearity, range, robustness, and system suitability studies. To ensure reliability and accuracy of the proposed method, recovery studies were carried out by mixing a known quantity of the standard solution with the sample at three different levels $(80 \%, 110 \%$, and $120 \%$ of assay value) with preanalyzed samples and contents were reanalyzed using the proposed method. Precision of the method was studied by making six injections of the standard solutions. The linearity of the method was established by triplicate injections of standard solution in the concentration range of 1.25 to $10.02 \mathrm{mg} / \mathrm{mL}$. The intraday precision was calculated using six injections at the higher concentration range $(10.02 \mathrm{mg} / \mathrm{mL})$ on the same day. This study was repeated on three consecutive days to obtain the interday precision. The limit of detection (LOD) and the limit of quantitation (LOQ) were determined from injections of progressively low concentrations of standard solution under optimized chromatographic conditions [19]. Ruggedness of the method was studied by carrying out experiment on instruments of different make. The robustness of the method was determined by making slight changes in chromatographic conditions like oven temperature, detector temperature, and carrier gas flowrate.

2.6. Statistical Analysis. The statistical analysis was carried out on Sigma plot software (Version 8.02 SPSS Inc., USA) and MS Excel 2007. The data were processed and recorded as mean \pm standard deviation of replicate measurements.

\section{Results and Discussion}

3.1. Method Development. The GC method was developed as a sensitive and robust screening procedure. The objective was to develop a sensitive and rapid gas chromatographic technique for the quantification of glycerin from marketed hair tonic formulation. We selected a marketed hair tonic containing $10 \mathrm{~mL} / 100 \mathrm{~mL}$ glycerin. The average runtime was about 


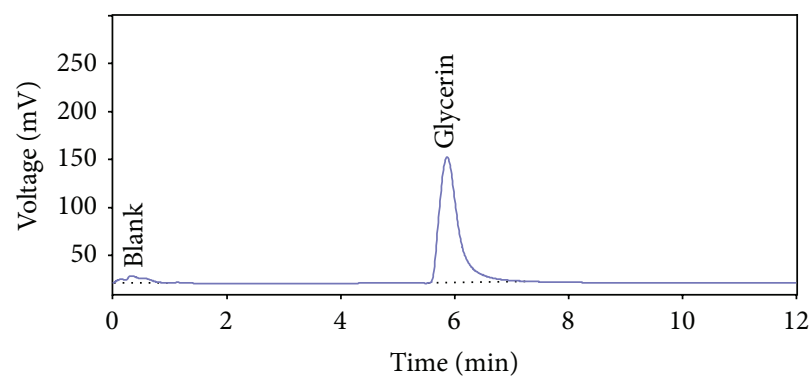

(a)

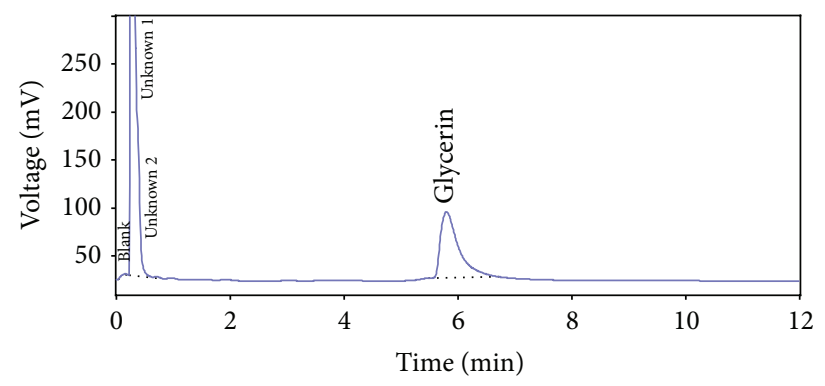

(b)

FIGURE 2: Representative chromatograms of analyte in standard solution (a) and sample solution (b).

12 minutes and glycerin elution occurred at about 6 minutes. In order to impart simplicity we used a single step dilution procedure using water as diluent in the sample preparation step. In order to achieve higher sensitivity the injection volume of $1 \mu \mathrm{L}$ was found optimal for the procedure and the sample was diluted to a concentration of $5.0 \mathrm{mg} / \mathrm{mL}$. For packed column analysis of glycerin using the proposed method, a better sensitivity was observed with water as diluent. In order to achieve further sensitivity slight changes in the chromatographic conditions like the injector and the detector temperature have been made before achieving the optimized condition. The chromatogram presented in Figure 2(b) presented sufficient resolution between analyte and the closely eluting peaks.

3.2. Method Validation. The presented gas chromatographic technique has been validated as per ICH Q2 (R1) guidelines following external standard method as discussed earlier.

3.2.1. System Suitability. System suitability was evaluated to verify if the chromatographic system was adequate for performing the analysis. The approximate results were theoretical plates $(N=12461)$, capacity factor $(k=3.98)$, peak asymmetry, or tailing factor $(t=1.79)$. The peak asymmetry observed does not affect the accuracy, precision, and the sensitivity of the method as observed from further study on method validation and the values for these parameters were satisfactory in accordance with the literature $[17,18]$ (Table 2).

3.2.2. Linearity and Range. The linearity [18] was determined with standard solutions in concentration range $1.25 \mathrm{mg} / \mathrm{mL}$ to $10.02 \mathrm{mg} / \mathrm{mL}$. The curve fitting was linear with regression factor $r^{2}=0.99$ and equation $y=907.60 x-509.90$ (Figure 1 ). The limit of detection (LOD) and limit of quantitation (LOQ) were determined in order to understand the minimum detectable amount and quantifiable amount of glycerine from the respective solutions. For standard solutions the values for LOD and LOQ were found to be $0.01 \mathrm{mg} / \mathrm{mL}$ and $0.05 \mathrm{mg} / \mathrm{mL}$, respectively (Table 2). Therefore, LOD and LOQ of this method presented the sensitivity of the procedure within the range of analysis under consideration.
TABLE 2: System suitability, sensitivity, and precision study for the proposed method.

\begin{tabular}{|c|c|}
\hline Parameters & Glycerin \\
\hline \multicolumn{2}{|l|}{ System suitability } \\
\hline Retention time (min) & $6.05 \pm 0.21$ \\
\hline Capacity factor & 3.89 \\
\hline Resolution & 5.68 \\
\hline USP tailing factor & 1.79 \\
\hline USP theoretical plates $(N)$ & 12461 \\
\hline \multicolumn{2}{|l|}{ Sensitivity } \\
\hline Limit of detection (LOD) (mg/mL) & 0.01 \\
\hline Limit of quantitation (LOQ) $(\mathrm{mg} / \mathrm{mL})$ & 0.05 \\
\hline $\begin{array}{l}\text { Content of glycerin } \mathrm{mL} / 100 \mathrm{~mL} \text { (label claim = } \\
10 \mathrm{~mL} / 100 \mathrm{~mL} \text { ) }\end{array}$ & $9.62 \pm 0.17$ \\
\hline \multicolumn{2}{|l|}{ Precision } \\
\hline \multicolumn{2}{|l|}{ Intraday } \\
\hline Repeatability $(\mathrm{mg} / 100 \mathrm{~mL})(n=5) \pm \% \mathrm{RSD}$ & $9.63 \pm 0.17$ \\
\hline \multicolumn{2}{|l|}{ Interday } \\
\hline $\begin{array}{l}\text { Mean resorcinol content from hair tonic } \\
\text { preparation }(\mathrm{mg} / 100 \mathrm{~mL})(\text { day } 1 / \text { day } 2 / \text { day } 3) \\
(n=3)\end{array}$ & $9.61 / 9.64 / 9.59$ \\
\hline$(\% \mathrm{RSD})($ day $1 /$ day $2 /$ day 3$)(n=3)$ & $0.21 / 0.16 / 0.19$ \\
\hline
\end{tabular}

3.2.3. Accuracy. The accuracy [18] was established across the range of concentration under study. In our study the accuracy of the method was analysed on the basis of recovery study. Three different spiked solutions at concentration range of $80 \%, 110 \%$, and $120 \%$ of the calculated assay value of the sample were prepared. The $80 \%$ solution was prepared by appropriately diluting the sample stock solution and the $110 \%$ and $120 \%$ solutions were prepared by spiking the sample stock with known amount of the standard stock solution (solution A). The results presented an accuracy of $99.91 \%$ to $100.80 \%$ with \%RSD 0.67 (Table 3 ). The results presented accuracy over the range of study [19].

3.2.4. Precision. In our study the precision [18] was calculated on the basis of repeatability and intermediate precision. Six 
TABLE 3: Recovery study.

\begin{tabular}{|c|c|c|c|c|c|c|c|}
\hline $\begin{array}{l}\% \text { of } \\
\text { nominal } \\
\text { value }\end{array}$ & $\begin{array}{c}\text { Estimated } \\
\text { concentration of } \\
\text { final solution in } \\
\mathrm{mL} / 100 \mathrm{~mL}^{*}\end{array}$ & $\begin{array}{c}\text { Estimated } \\
\text { recovery } \\
\%\end{array}$ & $\begin{array}{c}\text { Actual } \\
\text { concentration of } \\
\text { final solution } \\
(\mathrm{mg} / \mathrm{mL})^{*}\end{array}$ & $\begin{array}{c}\text { Average } \\
\text { assay }^{*} \\
(\mathrm{~mL} / 100 \mathrm{~mL})\end{array}$ & $\begin{array}{c}\text { Actual } \\
\text { recovery } \\
\%\end{array}$ & $\begin{array}{c}\text { Accuracy } \\
\%\end{array}$ & $\%$ RSD \\
\hline 100 & 9.62 & - & 4.89 & 9.62 & - & - & 0.01 \\
\hline 80 & 8.08 & 83.99 & 4.10 & 8.07 & 83.88 & 99.91 & \multirow{3}{*}{0.67} \\
\hline 110 & 10.48 & 108.94 & 5.37 & 10.57 & 109.87 & 100.80 & \\
\hline 120 & 11.35 & 117.98 & 5.78 & 11.38 & 118.29 & 100.20 & \\
\hline
\end{tabular}

* Average from three replicate injections from sample preparations.

The recovery study is carried out over three-concentration range.

TABLE 4: Robustness of the developed analytical procedure**.

\begin{tabular}{|c|c|c|c|c|c|c|c|c|c|c|c|c|}
\hline \multirow[b]{2}{*}{$\begin{array}{l}\text { Assay } \\
(\mathrm{mL} / 100 \mathrm{~mL})\end{array}$} & \multirow[b]{2}{*}{ Assay } & \multicolumn{3}{|c|}{ Analysts } & \multicolumn{2}{|c|}{ Instruments } & \multicolumn{3}{|c|}{ Storage condition } & \multicolumn{3}{|c|}{ Chromatographic condition } \\
\hline & & 1 & 2 & 3 & I & II & $20^{\circ} \mathrm{C}$ & $30^{\circ} \mathrm{C}$ & $45^{\circ} \mathrm{C}$ & $\begin{array}{c}\text { Column } \\
\text { temperature } \\
\left( \pm 5^{\circ} \mathrm{C}\right)\end{array}$ & $\begin{array}{c}\text { Detector } \\
\text { temperature } \\
\left( \pm 5^{\circ} \mathrm{C}\right)\end{array}$ & $\begin{array}{l}\text { Carrier gas } \\
\text { flowrate }^{\#}\end{array}$ \\
\hline & 9.62 & 9.61 & 9.63 & 9.66 & 9.60 & 9.62 & 9.63 & 9.62 & 9.59 & 9.66 & 9.63 & 9.61 \\
\hline
\end{tabular}

** Each analysis was carried out in three replicates.

\# A 5\% change in the carrier gas flowrate results in no appreciable change in the retention time of the analyte $(P<0.05)$.

sample solutions at $100 \%$ of test concentration were separately prepared from the hair tonic received as gift sample and analyzed using the analytical procedure under study. The intermediate precision was obtained by triplicate injections of the same solution on three different days. The intraday and interday precision values were calculated using the standard curve used for sample analysis (Figure 1). The intraday precision presented an assay value of $9.63 \mathrm{~mL} / 100 \mathrm{~mL}$ with $\%$ RSD value of 0.17 and for interday the assay varied from $9.59 \mathrm{~mL} / 100 \mathrm{~mL}$ to $9.64 \mathrm{~mL} / 100 \mathrm{~mL}$ with \%RSD 0.16 to 0.21 , respectively, making the analytical procedure precise within the range of study.

3.2.5. Specificity. The representative chromatogram of the sample (Figure 2(b)) presents sufficient resolution between the analyte peak and closely eluting peaks and no appreciable interference of the unknown components with the analyte peak. This renders the method to be specific [18] for the analysis of glycerin in presence of other components present in the sample matrix.

3.2.6. Robustness. The robustness [17] of the method was studied with variations of analyst, instruments, and solution stability on different storage conditions. The variations were also carried out in the column or oven temperature used in analysis. The results were found within tolerance limits (Table 4). The results of this robustness study (Table 4) presented the method to be robust for the analysis of resorcinol from any formulation at a concentration as low as $0.05 \mathrm{mg} / \mathrm{mL}^{-1}$ (Table 2).

\section{Conclusion}

The developed gas chromatographic method was simple, rapid, sensitive, precise, and selective for the estimation of glycerin from hair tonic formulation containing glycerin as one of its component. The method was validated in terms of linearity and precision in the studied concentration range as per ICH guidelines. The retention time of glycerin was only $6.05 \pm 0.21$ minutes and there was sufficient resolution between the analyte peak and closely eluting peaks. Thus we can conclude that this method can be used for routine analysis of glycerin from marketed hair tonic formulations containing glycerin.

\section{Conflict of Interests}

The authors declare that there is no conflict of interests regarding the publication of this paper.

\section{Acknowledgments}

The authors acknowledge all members of $\mathrm{R} \& \mathrm{D}$ section for their kind cooperation and support. The authors also thank the management and board members for their invaluable support and encouragement.

\section{References}

[1] R. C. Rowe, P. J. Sheskey, and M. E. Quinn, Handbook of Pharmaceutical Excepients, Pharmaceutical Press, London, UK, 6th edition, 2009.

[2] J. Meyer, B. Marshall, M. Gacula Jr., and L. Rheins, "Evaluation of additive effects of hydrolyzed jojoba (Simmondsia chinensis) esters and glycerol: a preliminary study," Journal of Cosmetic Dermatology, vol. 7, no. 4, pp. 268-274, 2008.

[3] N. Atrux-Tallau, C. Romagny, K. Padois et al., "Effects of glycerol on human skin damaged by acute sodium lauryl sulphate treatment," Archives of Dermatological Research, vol. 302, no. 6, pp. 435-441, 2010. 
[4] M. Breternitz, D. Kowatzki, M. Langenauer, P. Elsner, and J. W. Fluhr, "Placebo-controlled, double-blind, randomized, prospective study of a glycerol-based emollient on eczematous skin in atopic dermatitis: biophysical and clinical evaluation," Skin Pharmacology and Physiology, vol. 21, no. 1, pp. 39-45, 2008.

[5] L. Oliveira, J. Madrid, G. Ramis et al., "Adding crude glycerin to nursery pig diet: effect on nutrient digestibility, metabolic status, intestinal morphology and intestinal cytokine expression," Livestock Science, vol. 167, pp. 227-235, 2014.

[6] L. Bournay, D. Casanave, B. Delfort, G. Hillion, and J. A. Chodorge, "New heterogeneous process for biodiesel production: a way to improve the quality and the value of the crude glycerin produced by biodiesel plants," Catalysis Today, vol. 106, no. 1-4, pp. 190-192, 2005.

[7] C. Benaim-Pinto, "Topical glycerin in seborrhoeic dermatitis," The Lancet, vol. 2, no. 7785, pp. 1037-1038, 1972.

[8] A. Hautfenne, "Standard methods for the analysis of oils, fats and derivatives," International Union of Pure and Applied Chemistry, vol. 54, no. 6, pp. 1257-1295, 1982.

[9] M. L. Pisarello, B. O. Dalla Costa, N. S. Veizaga, and C. A. Querini, "Volumetric method for free and total glycerin determination in biodiesel," Industrial \& Engineering Chemistry Research, vol. 49, no. 19, pp. 8935-8941, 2010.

[10] A. M. A. P. Fernandes, D. U. Tega, J. L. P. Jara et al., "Free and total glycerin in biodiesel: accurate quantitation by easy ambient sonic-spray ionization mass spectrometry," Energy \& Fuels, vol. 26, no. 5, pp. 3042-3047, 2012.

[11] R. L. Self, "Direct analysis in real time-mass spectrometry (DART-MS) for rapid qualitative screening of toxic glycols in glycerin-containing products," Journal of Pharmaceutical and Biomedical Analysis, vol. 80, pp. 155-158, 2013.

[12] T. Uchimoto, Y. Iwao, K. Takahashi et al., "A comparative study of glycerin fatty acid ester and magnesium stearate on the dissolution of acetaminophen tablets using the analysis of available surface area," European Journal of Pharmaceutics and Biopharmaceutics, vol. 78, no. 3, pp. 492-498, 2011.

[13] L.-C. Wu and C.-M. Cheng, "Flow-injection enzymatic analysis for glycerol and triacylglycerol," Analytical Biochemistry, vol. 346, no. 2, pp. 234-240, 2005.

[14] N. Simonzadeh and B. Ronsen, "An isocratic HPLC method for the determination of sorbitol and glycerol in pharmaceutical formulations," Journal of Chromatographic Science, vol. 50, no. 7, pp. 644-647, 2012.

[15] K. Molever, "Simplified assay of diethylene glycol and ethylene glycol in various raw materials by capillary gas chromatography," Journal of Cosmetic Science, vol. 61, no. 3, pp. 225-234, 2010.

[16] T. Zhou, H. Zhang, and G. Duan, "Simultaneous determination of diethylene glycol and propylene glycol in pharmaceutical products by HPLC after precolumn derivatization with $\mathrm{p}$ toluenesulfonyl isocyanate," Journal of Separation Science, vol. 30, no. 16, pp. 2620-2627, 2007.

[17] The United States Pharmacopeia, vol. 1, U.S. Pharmacopeial Convention, Rockville, Md, USA, 38th edition, 2008.

[18] ICH (Q2,R1), "Note for guidance on validation of analytical methods: definitions and terminology," in Proceedings of the International Conference on Harmonisation, pp. 9-13, 1994.

[19] S. Ahuja and S. Scypinski, Hand Book of Modern Pharmaceutical Analysis, Academic Press, New York, NY, USA, 2005. 

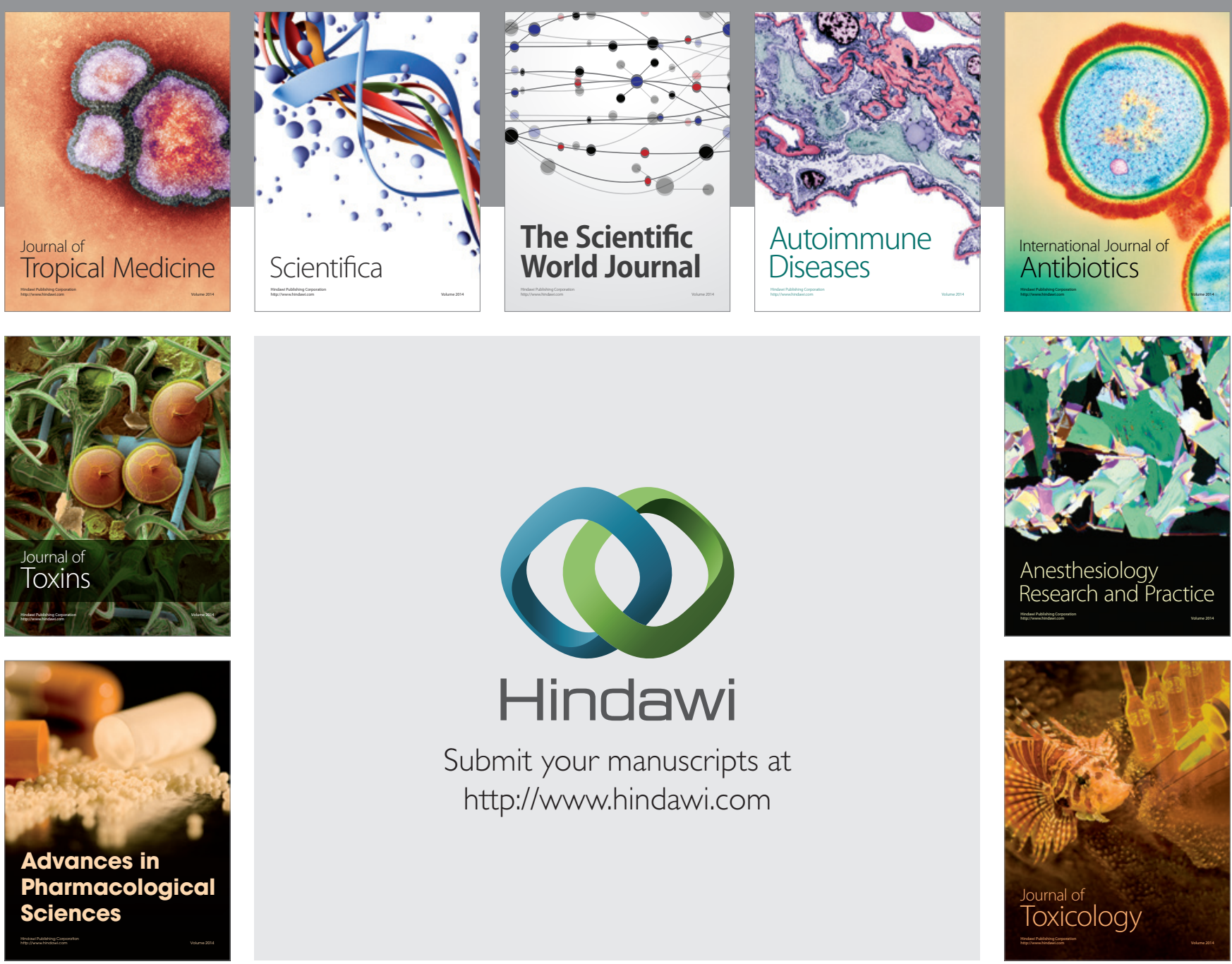

\section{Hindawi}

Submit your manuscripts at

http://www.hindawi.com
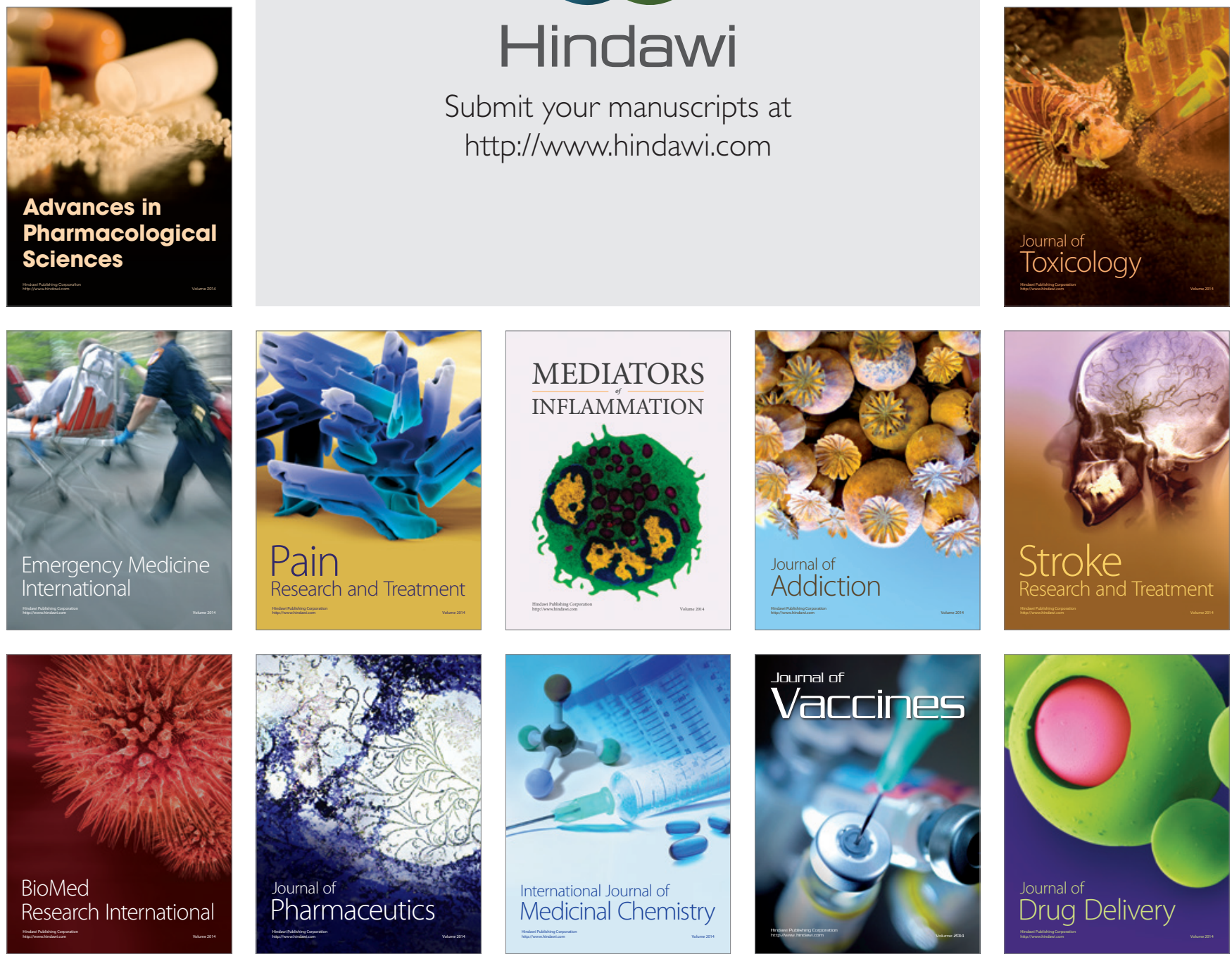